\title{
The rise and fall of open regionalism? Comparative reflections on regional governance in the Southern Cone of Latin America
}

\section{NICOLA PHILLIPS}

ABSTRACT This article argues that the original framework of 'open regionalism' underpinning the Mercosur is petering out, and consequently the regional governance project in the Southern Cone is undergoing a process of redefinition. The article seeks to understand the nature of this redefinition, and contends that this task requires a re-orientation of some of the prevalent ways in which the study of regionalism is approached. Specifically, it highlights the limitations of an understanding of regionalism merely as a reflection of domestic processes, and instead argues for a greater attention to processes of regionalisation and their complex relationship with both regionalism and domestic political economy.

If the sceptics and doomsayers are to be believed, the prognosis for Latin American regionalist projects is not encouraging. The limited achievements to date of most subregional blocs, the continuing vitality of bilateralism, the threat from the wider hemispheric integration project in the Americas, enduring political instability in various countries across the region, the impact of global financial volatility, and recurrent economic crisis are not, at least according to dominant understandings, conditions conducive to the survival and health of regional integration initiatives. The Mercosur ${ }^{1}$ is frequently seen as likely either to disintegrate under its own weight or alternatively to be swallowed up into whatever sort of Free Trade Area of the Americas (FTAA) might come into being in the next few years; likewise the Andean, Central American and Caribbean blocs are commonly depicted as in a process of stagnation, and equally likely to lose their rationale should hemispheric free trade be negotiated successfully. Observation of the splintering of the Mercosur, particularly, has meant that much of the hubris surrounding 'new' or 'open' regionalism in the early 1990s has given way to a scepticism about its viability and future prospects. At least at this level, the parallels with contemporary discussions about APEC and ASEAN, reflected in the present collection of papers, are striking.

What I wish to do here is not only take issue with the idea that the Mercosur is at death's door, but also to suggest that the endless arguments about whether it is 
or not are not the most fruitful way of understanding contemporary regional governance in the Southern Cone. On an empirical level, I argue that, rather than being in a process of obsolescence, the Mercosur project is undergoing an important redefinition and that this is producing, with some parallels to the process underway in Asia, a rather different kind of regionalism from the 'open regionalism' model which prevailed in the 1990s. On a conceptual level, moreover, I suggest that understanding the nature of this redefinition demands a reorientation of some of the prevalent ways in which the study of regionalism is approached. Most especially, domestic political economy is usually taken as constitutive of regional political economy and consequently regional political economy is depicted simply as an extension, or a magnification, of domestic processes. The result is the reinforcement of a rather narrow focus on formal state-led regionalist projects, which obscures the social processes of regionalisation that surround and overlap with them, ${ }^{2}$ and indeed has been pivotal in producing what I consider to be rather misleading accounts of the Mercosur's imminent demise. What is needed, I suggest, is an understanding of regional political economy as involving a set of dynamics which reach beyond formal regionalist, state-led processes, through which lens we can better understand the reconfiguration of regional governance in the Southern Cone.

\section{Open regionalism in the Southern Cone}

As in Asia, the new regionalism in Latin America has conformed broadly with a model of 'open regionalism', predicated on a perception of the merits of unilateral trade liberalisation for increased and more effective participation in the global economy. The label 'open regionalism', however, does not tell us very much else about the sorts of regionalism that have emerged on the basis of this broad rationale. Here, as Kanishka Jayasuriya argues in his contribution to this issue, a 'regional governance' framework offers significantly more value, particularly to a comparative exercise. Let us set out quickly the four central elements he outlines as comprising a regional governance project:

1. a stable set of international economic strategies;

2. a distinctive set of governance structures which enables regional economic governance;

3. a set of normative or ideational constructs that not only makes possible a given set of regional governance structures but also makes possible the very definition of the region;

4. a convergence of domestic coalitions and political economy structures across the region, which would facilitate the coherent construction of regional political projects.

When taken to the Southern Cone, these four components proffer not only useful comparisons with Asian regionalism, but they also constitute a useful starting point for looking at the pressures under which the Mercosur project laboured during the 1990s. The first of these, as already suggested, offers a direct similarity with the East Asian region in the adoption of an 'open regionalism' 
model of trade liberalisation. Despite some significant sectoral variation, this model filled its brief relatively well, especially in the early years of the Mercosur, as a mechanism for reinforcing domestic trade liberalisation as well as spurring a significant growth in intra- and extra-Mercosur trade. Between 1990 and 1995, for example, exports increased by an annual average of $28.4 \%$ and imports by 27.8\%. Between 1990 and 1996 Mercosur's share of total regional exports increased from $8.9 \%$ to $22.6 \%$ (INTAL, 1997: ii). Nevertheless, one of the most notable features of the Mercosur is that it remains significantly inward-looking, measured in terms of trade relative to GDP. While the percentages increased consistently through the 1990s, the figures in Table 1 still demonstrate that the impact of the 'open regionalism' strategy was not to make the region appreciably more 'open' than in its pre-Mercosur days. In Brazil and Argentina especially, the internal market remains considerably more important than the external sector.

The second element of the framework also suggests some similarities between Southern Cone and Asian regionalism, in that the governance structures in both have remained largely informal rather than rules-based. The Mercosur is institutional structure, as has often been noted, is wholly intergovernmental rather than supranational, and does not rest on an extensive legal framework similar to that of the NAFTA. Rather, while a number of treaties and agreements underpin the

TABLE 1

Selected trade openness measures, 1990-99 (\%)

\begin{tabular}{lrrrrrrrrrrr}
\hline & 1990 & 1991 & 1992 & 1993 & 1994 & 1995 & 1996 & 1997 & 1998 & 1999 \\
\hline Imports/GDP & & & & & & & & & & \\
W Hemisphere & 9.9 & 9.5 & 10.2 & 10.5 & 11.2 & 11.7 & 11.9 & 12.4 & 12.5 & 13.3 \\
NAFTA & 10.2 & 9.8 & 9.3 & 9.7 & 9.9 & 11.0 & 11.2 & 11.3 & 11.9 & 11.9 \\
LAC & 10.1 & 8.2 & 10.2 & 11.3 & 10.8 & 12.0 & 12.3 & 12.5 & 14.9 & 19.7 \\
LAC excl. Mexico & 8.0 & 7.4 & 10.2 & 10.7 & 10.4 & 11.0 & 10.8 & 11.9 & 11.7 & 13.8 \\
Mercosur & $\mathbf{4 . 7}$ & $\mathbf{4 . 2}$ & $\mathbf{6 . 3}$ & $\mathbf{6 . 9}$ & $\mathbf{7 . 5}$ & $\mathbf{7 . 6}$ & $\mathbf{7 . 7}$ & $\mathbf{8 . 7}$ & $\mathbf{8 . 6}$ & $\mathbf{9 . 6}$ \\
Andean & & & & & & & & & & \\
Community & 12.5 & 13.7 & 16.4 & 16.9 & 15.3 & 15.8 & 15.2 & 15.8 & 15.4 & 12.8 \\
CARICOM & 36.3 & 40.2 & 41.3 & 35.9 & 40.5 & 45.3 & 39.5 & 45.5 & n/a & n/a \\
CACM & 24.2 & 24.6 & 23.6 & 26.6 & 25.8 & 24.6 & 27.6 & 25.4 & 27.7 & 33.9 \\
& & & & & & & & & & \\
Exports/GDP & & & & & & & & & & \\
W Hemisphere & 8.5 & 8.3 & 8.5 & 8.5 & 9.4 & 10.3 & 10.5 & 10.8 & 10.2 & 10.6 \\
NAFTA & 8.1 & 8.2 & 8.3 & 8.2 & 9.2 & 10.3 & 10.5 & 10.9 & 10.3 & 10.3 \\
LAC & 12.3 & 9.9 & 11.3 & 11.2 & 11.6 & 13.2 & 13.8 & 14.0 & 13.4 & 19.7 \\
LAC excl. Mexico & 11.3 & 8.8 & 10.8 & 10.5 & 10.5 & 10.2 & 10.4 & 10.6 & 9.5 & 13.3 \\
Mercosur & $\mathbf{7 . 5}$ & $\mathbf{5 . 7}$ & $\mathbf{7 . 8}$ & $\mathbf{7 . 8}$ & $\mathbf{7 . 5}$ & $\mathbf{7 . 1}$ & $\mathbf{7 . 0}$ & $\mathbf{7 . 3}$ & $\mathbf{7 . 3}$ & $\mathbf{8 . 9}$ \\
Andean & & & & & & & & & & \\
Community & 23.0 & 18.9 & 17.1 & 16.9 & 17.1 & 15.8 & 18.8 & 17.2 & 13.5 & 15.7 \\
CARICOM & 30.5 & 28.0 & 27.4 & 21.9 & 32.6 & 32.0 & 27.9 & 28.5 & 16.9 & n/a \\
CACM & 15.9 & 16.1 & 15.5 & 14.7 & 15.0 & 16.5 & 17.7 & 17.0 & 19.8 & 20.9 \\
\hline
\end{tabular}

Source: IDB Integration and Regional Programs Dept, Integration and Trade in the Americas, December 2000. 
regional economic strategies of the Mercosur, the latter have been marked by an important degree of ad hoc decision making, particularly in the progressively frequent instances of violations by member countries of core agreements in times of crisis. In part this highly politicised and unstable set of governance structures is engendered by the customs union model which underpins the Mercosur project approximates and which, in contrast to a 'free trade area' model, requires the development of policy harmonisation beyond a commitment to the removal of barriers to market access (Bernier \& Roy, 1999: 73). Associated governance projects are thus in theory defined largely by the political negotiation of policy harmonisation and the construction of the institutions necessary to sustain such an arrangement. In good part also, the intergovernmentalism of the Mercosur reflects an ingrained Brazilian reticence on the matter of institutionalisation, as well as the anti-statist thrust of the manner in which neoliberalism was pursued in Argentina under the Menem governments of the 1990s. The point, at any rate, is that the Mercosur project lacks any form of robust institutionalisation that might facilitate a more rules-based governance structure.

The third and fourth elements of Jayasuriya's framework-relating to ideational constructs and domestic political economy structures-are the most important for our purposes here, and can be taken in conjunction with each other. In contrast with the East Asian region, the definition of the Southern Cone 'region' has not been approached in cultural terms; indeed, one of the notable features of Southern Cone regionalism has been the absence of the sort of underlying regional 'identity' which is found, to a greater or lesser extent, in a number of other regional governance projects in the Americas. ${ }^{3}$ The ideational constructs that have underpinned Southern Cone regionalism have been of the sort which do not lend themselves obviously to the task of defining a region-namely, the ideological constructs that derive from the broadest of commitments to democracy and neoliberalism. Particularly in respect of the neoliberal ideational framework, moreover, the divergences between Southern Cone countries have been central to the fragmentation of the incipient project of regional governance and, indeed, have been inimical to a convergence of domestic political economy structures and domestic coalitions of the sort envisaged in Jayasuriya's point 4. Notwithstanding important points of diversity within the Asian region, the emergence of a model of 'embedded mercantilism' represented a relatively robust uniformity between domestic political economies. While the same might be said of the Latin American region in the widespread adoption of a roughly Anglo-American neoliberalism, a suggestion of uniformity is highly misleading, and particularly so in the context of the Southern Cone, reflecting both historical-institutional specificities and the highly variegated relationships of the national economies with the world economy and globalisation processes. A full account of these divergences between domestic political economy structures is beyond the scope of this paper, but the relevant point is that they have been constitutive of sharply contrasting visions of regionalism between the member countries of the Mercosur, to the extent that there has not been a solid underlying ideational or normative foundation for the regional governance project.

In this respect one of the principal cleavages relates to the nature of the Brazilian political economy. On the one hand, the relationship of the state with 
foreign capital has been significantly at variance with that of neighbouring countries, in that external financing over the course of the 1990s was more abundantly and readily available to Brazil than to most other Latin American economies. While most countries were obliged to exercise fiscal responsibility in order to attract capital, investment flowed into Brazil irrespective of conditions in which bankrupt state banks continued to issue credit and in which the Central Bank remained one of the least independent in the region (Kingstone, 1999: 136). Given that the rationale for regionalism rested on the twin pillars of commercial expansion and the attraction of foreign investment funds, the impulsion towards the Mercosur was thus notably less strong for Brazil than it was for its partners. On the other hand, Brazil is distinguished in the subregion by its diversified trade structure and the volume of its extra-regional trade, to the extent that even its commercial interests are much less linked with the regional marketplace than those of neighbouring countries. For these reasons, the new multilateral round of trade negotiations is of considerably more concern to Brazil than regional integration. Indeed, the reticence of the Brazilian government in the early days of the Mercosur-and more recently towards the hemispheric integration projectcan be explained in large part by the potential trade-off it represents with multilaterally agreed liberalisation provisions in the World Trade Organization (WTO) (de Paiva Abreu, 2003: 23). Brazilian engagement with regional integration, in this sense, needs to be understood as motivated by strategic and political goals, most of which relate to the construction of subregional leadership as a means of mediating the hegemony of the USA in the hemispheric and multilateral arenas. Certainly this strategic vision of the Mercosur became considerably more robust as the hemispheric integration project picked up speed in the later part of the 1990s, along with negotiations for economic co-operation with the European Union (EU). The Brazilian indifference to regionalism of the mid-1990s has thus been progressively replaced by an activism orientated towards strengthening the Mercosur as a strategic and political platform (see Phillips, 2000: 393-394).

In Argentina and the smaller member countries, as suggested, the much greater dependence on the regional marketplace, together with the more pronounced dependence on and vulnerability to external capital flows, have meant that participation in the Mercosur has been dictated far more by economic necessity than was the case for Brazil. The Argentine vision of regionalism consequently has been expounded by governmental actors as resting on the expansion of the membership of the regional bloc, and the widening in this sense of the open regionalism project. While sharing the goal of 'deepening' regionalism, Argentine positions have consistently been orientated also towards an extension of the Mercosur market, or conversely towards opening extra-regional markets by means, primarily, of inter-bloc negotiations. The Uruguayan and Paraguayan focus has fallen somewhere between the 'deepening' and 'expansion' options, but their principal concern, not surprisingly, has been with the need for institutionalisation in order to ensure adequate representation of their interests in a process dominated by the interaction of Argentina and Brazil. The dominance of primary and agricultural exports in the three smaller member countries, in addition, shapes a rather different set of structural and negotiating imperatives in 
the regional project from those of the Brazilian government and sections of the Brazilian business community. In a nutshell, the interests of the latter are tied principally to trade concerns, conforming closely with the 'open regionalism' rationale of using unilateral bloc-driven liberalisation to propel reciprocal liberalisation in other markets and at other levels. The interests of the Argentine, Uruguayan and Paraguayan governments are dictated by a broader set of developmental imperatives, of which the attraction of capital and the promotion of industrialisation are foremost.

The upshot, in sum, is that there has been little convergence of domestic political economy structures in the Mercosur, and certainly no underlying 'model' such as that of embedded mercantilism from which a coherent and stable set of associated international strategies might have arisen. Indeed, the acceleration of political conflict and dispute over the course of the 1990s suggests that, if anything, the underlying divergences between domestic coalitions and political economy structures have become more, rather than less, pronounced, to the extent that the associated strategies of open regionalism have become less, rather than more, viable. Certainly the progress made over the 1990s towards a stable regional governance project was not impressive. By the start of the 2000s, the Mercosur still constituted a very imperfect customs union, which had made significant strides in the removal of tariff barriers to trade and the attraction of FDI, but precious little progress in basic areas such as the harmonisation of customs procedures, and in important areas such as trade in services, exchange rate co-ordination, intellectual property, government procurement, the free movement of workers, and institutionalisation (Phillips, 2001: 568). For a time in the latter part of the 1990s, the movement by the Brazilian government towards a greater privileging of the Mercosur in its foreign and foreign economic strategies suggested a convergence, at least, on a commitment to the regional governance project. Given that this commitment was premised on significantly divergent motives and interests, however, it did little to paper over the evident fissures in the bloc and certainly did not approximate a convergence of the disparate visions of regionalism. To this extent, in some similarity to the manner in which responses to financial crisis in Asia pulled apart the domestic commonalities underpinning APEC and the East Asian region, the lack of any such robust commonalities in the Southern Cone region has meant that the regionalist project has remained distinctly shallow and fragile.

Two more conjunctural factors come into play at this point. The first relates to the financial and economic crises that have dominated the landscape of the Southern Cone since the late 1990s, first with the Brazilian devaluation of 1999 , and then more profoundly with the Argentine default and devaluation of 2001, and its knock-on effects in Uruguay and Brazil in mid-2002. The effect has been to undermine further the prospects for a convergence of domestic coalitions, and also to fracture further the consensus surrounding the Mercosur itself. The Uruguayan government, particularly, appears to have started down a 'Mercosursceptic' path, opening a rift with the rather more optimistic Brazilian vision of the future of regionalism. Uruguayan President Batlle has branded ideas of a common currency for the Mercosur as 'absolutely impossible' (La Nación, 27 March 2002), and the government showed little hesitation in 2002 in imple- 
menting counter-measures against the impact of the Argentine devaluation. Moreover, the Uruguayan government became more strident in its preference for an FTAA over the subregional bloc at the start of 2002, and in the interim for bilateral relations with the USA. An eagerness to engage in bilateral negotiations has also been in evidence in Argentina, and Chile signed a bilateral agreement with the USA in December 2002.

The second conjunctural pressure on subregionalism stems from the hemispheric integration project. If existing subregional arrangements are based on the extension of trade preferences to member countries, the construction of an FTAA will necessarily and logically remove the rationale for the smaller trade blocs it encompasses. The upshot, according to this argument, is that the loss of their economic rationale will generate a process by which the structures of preferences and tariffs that define these blocs are gradually or suddenly erased by the provisions of hemispheric free trade. Such is certainly the vision that the USA brings to the negotiating table: especially for business and members of Congress, subregional blocs are perceived to be simply the forerunners and facilitators of the 'levelling' of the hemispheric playing field implied by the FTAA. This vision of 'hemispheric globalisation' thus brings with it the redundancy of subregional blocs (SELA, 1999: 36-37). While this latter argument should be challenged (see Phillips, 2003), nevertheless an FTAA does necessarily augur a reconfiguration of the nature of subregionalism in order to accommodate the rules agreed at the hemispheric level, and consequently the function of blocs such as the Mercosur becomes open to considerable question. In a situation in which the Mercosur is already beset by myriad internal tensions, including preferences for bilateralism and an ambivalent leadership, the threat to subregionalism from an FTAA has been seen by many to augur its demise. As Paul Cammack (2001) argues, for instance:

Mercosur ... is an ineffective regional association with little remaining capacity to contribute to regional or global integration, and little capacity to promote other goals. It is likely to be marginalised by profound differences of perspective between its major partners, and overtaken by broader processes such as the move towards a Free Trade Area of the Americas.

I suggest, however, that such a vision issues from a particular way of thinking about regionalism, and specifically from a focus on the formal, regionalist processes associated with the regional governance project. It would seem that much of the problem emerges from the tendency to view regions as simply 'nations writ large', ${ }^{4}$ in the sense that regionalism is portrayed simply as the magnification of domestic economic activity or sets of policy priorities. In other words, such a perspective assumes that the regional arena is a modus operandi for domestic modes of capitalist organisation. The 'nation writ large' understanding of regionalism might identify ways in which domestic policy strategies can be influenced by the existence of a regional bloc, but allows limited room for the notion that strategies might be informed, shaped and determined by the processes associated with the regional project. For this we need an understanding of processes of regionalisation, parallel to our analysis of formal regionalist processes. In the context of the Southern Cone, these processes of regionalisation are significantly stronger than the processes of state-led regionalism, but more- 
over serve to buttress the regionalist governance project in ways which cast doubt on its envisaged obsolescence.

\section{The contours of market-led regionalisation}

Regionalisation, like globalisation, is not a state-led project but rather represents 'combinations of historical and emergent structures-a complex articulation of established institutions and rules and distinctive new patterns of social interaction between non-state actors' (Gamble \& Payne, 1996: 250). The relevant processes of regionalisation are thus manifold, and cannot all be covered in a single article. ${ }^{5}$ Our concern here, in the first instance, is with processes of market-led regionalisation, which are grounded specifically in the gradual regionalisation of the strategies and structures of firms. This re-organisation of capital has propelled the construction of a genuinely regional market, which crystallises around the Mercosur, though does not correspond exactly with the borders of its membership. It rests, on the one hand, on the transnationalisation strategies of domestic firms, and on the other on the strategies of foreign investors and corporations aiming to erase the limitations to their activity posed by national boundaries within the Mercosur.

Corporate strategies linked to the Mercosur divide into two groups, the first relating to purely commercial strategies, found particularly in capital goods sectors, the second to more direct productive strategies. The latter strategies have been most characteristic of transnational corporations (TNCs) with operations in Argentina and Brazil, while complementation between local firms in these two countries has been concentrated in production activities linked with consumer and intermediate goods (López \& Porta, 1995: 255-256). In many respects it is the market strategies of TNCs that have been most pivotal in carving out regionally defined modes of business organisation in the wider Mercosur arena, and in turn the investment strategies of these corporations have largely been shaped by the existence of a subregional bloc. While foreign investment in Mexico, Central America and the Caribbean over the 1990s was directed predominantly at generating international competitiveness (particularly in firms and sectors exporting to the USA), across the Southern Cone the target of capital inflows was consistently local and subregional markets were constructed-and comparatively protected-by regional integration projects (ECLAC, 2001: 55). In other words the focus of transnational capital in the Southern Cone has been the possibilities afforded by investment in local markets to make inroads into the Mercosur itself, along with the advantages proffered by the subregional economy of scale. In some cases, in addition, TNCs have sought to take advantage of the special provisions afforded to certain sectors-most notably the automotive sector-in the Treaty of Asunción which founded the Mercosur in 1991.

The strategies of foreign-owned TNCs, as a result, have moved consistently away from a national focus to a regional one. Recent survey data gathered by Oliveira Holzhacker and Guilhon Albuquerque (2002) suggest, for instance, that about $85 \%$ of EU TNCs (and $63 \%$ of the largest Brazilian firms) have elaborated strategies aimed at the Mercosur market. The clearest dimension of this shift is reflected in the rationalisation of operations in the Southern Cone, in terms both 
of activity and of management structures. The aim and result of rationalisation has been that the subsidiaries of TNCs in various parts of the region have become significantly more specialised, and production activities progressively defined in regional rather than national terms. Examples include firms such as Nestlé, Unilever, General Motors, Coca Cola, and Procter and Gamble (ECLAC, 2001: 96). Similar processes are visible in the restructuring of the pharmaceuticals industry, for instance, and especially in the automobile sector. Along with such rationalisation strategies, investment strategies over the 1990s also became more conditioned by the notion of regional expansion, and in national markets thus became styled as stepping stones to the rest of the Southern Cone, or indeed Latin America. The example of services markets in Chile stands out in this regard (ECLAC, 2001: 100). Conversely, the appeal of a Mercosur market has bolstered the appeal to TNCs of maintaining a presence in various national economies. This is most especially the case for Argentina, in particular in the automobile, capital goods and household appliances sectors (López \& Porta, 1995: 258).

Likewise, the transnationalisation strategies of Southern Cone firms have been focused to a preponderant extent on the regional marketplace and have only exceptionally been genuinely 'global' in character. These regionalisation strategies are particularly pronounced in Argentina, where Mercosur countries (including Chile and Bolivia) constitute the primary destination for firms' foreign direct investment strategies. Take the example of the firm socma. ${ }^{6}$ While its activities are still concentrated in Argentina, its presence in Brazil (probably the strongest of Argentine firms) has steadily and significantly increased since about 1994, and its organisational and management structures are gradually being reconfigured to take account of this 'bi-national' profile. ${ }^{7}$ Its operations in Uruguay have similarly gained in prominence in a number of sectors, ${ }^{8}$ but crucially the automotive sector has been dominant in both SOCMA's own regional expansion and in the broader processes of corporate regionalisation that have crystallised in the Mercosur arena since the mid-1990s. The importance of other Latin American markets should not be overlooked, but here there is a clear distinction between Argentine firms' commercial strategies, on the one hand, and, on the other, investment strategies involving the physical establishment of industrial operations. Destinations for the former are more regionally diversified than for the latter, for which Southern Cone economies are overwhelmingly preponderant. Companies such as Bagó, IMPSAT and the oil company YPF have industrial operations in North America (mainly in Mexico) and the latter two indeed might qualify as operational on a 'global' stage, but an altogether much greater number (including Arcor, IMPSA, Pérez Companc, Sancor, and SOCMA) have an almost exclusively 'South American' profile in terms of physical operations, in which Mercosur countries again are overwhelmingly preponderant (see Chudnovsky et al, 1999: 123-124).

While in Argentina the focus has fallen emphatically on Mercosur markets, the profile of Chilean firms' strategies has been one dominated rather more by the wider Latin American market, although within this rather more diversified structure Southern Cone economies still stand out. The Latin American market has been especially pivotal in the turn towards non-natural resource-based exports, encompassing both manufactured products and non-financial services 
(Chudnovsky et al, 1999: 266), and the Mercosur market has been particularly important given the lack of competitiveness of such export products in both wider regional and global arenas. With regard to Chilean investment, moreover, Southern Cone economies overshadow destinations in both Latin America and in the rest of the world. Argentina constitutes the most important destination, accounting in 1997 for some 43.6\% of total Chilean investment, followed by Peru and then Brazil, the latter accounting for $10.8 \%$ in the same year (Chudnovsky et al, 1999: 281).

Such strategies have been less common in Brazil, where TNCs remain more dominant and the majority of domestic firms have been absorbed by transnational interests (Chudnovsky et al, 1999: 9). It is notable that the activities of a good number of these TNCs in Brazil are orientated towards the domestic market rather than towards external trade. One side-effect of this comparatively low level of internationalisation is that the onslaught of competitive pressure for Argentine, Uruguayan and Paraguayan firms was considerably greater than for Brazilian firms (as demonstrated by Oliveira Holzhacker and Guilhon Albuquerque's (2002) data), given both the relatively protected nature of the Brazilian market and the fact that Brazilian industrial products were already competitive in the Southern Cone arena. As we have seen, it is also the case that the attraction to Brazil of Mercosur economies as trading partners is significantly less than vice versa. Nevertheless, leaving aside questions of volume, over the course of the 1990s the Mercosur market was the most dynamic destination for Brazilian exports, growing at an annual average of $26.9 \%$ against an annual average growth rate of only $6.3 \%$ for total exports. Exports to Mercosur countries were also concentrated in manufactured products, which accounted for about $70 \%$ of total exports to Mercosur countries in 1998. Southern Cone economies are also important as sources of imports, among which Argentine agricultural products stand out, along with cars, footwear and food products (see da Motta Veiga, 1999: 315, 325). Brazilian foreign investment in services is concentrated overwhelmingly in Mercosur markets, and furthermore Brazilian investment in Mercosur economies is dominated by investment in services sectors, accounting for two-thirds of total Brazilian investment in Uruguay and almost $100 \%$ of the total directed from Brazil to Paraguay. Argentina is the preponderant destination for Brazilian investment in financial services (Page, 2001: 56). Crucially, taking us back to earlier points in this section, this expansion of both commercial and investment engagement with the Mercosur arena has been notable for the growth of the participation in it of TNCs, which increased by an annual average of $56 \%$ over the 1990-97 period (da Motta Veiga, 1999: 329).

For their part, the attitude to the Mercosur of small and medium sized enterprises (PYMEs, in Spanish) across the region has been, inevitably, mixed. On the one hand, the threat from imported goods has produced caution and, in some cases, hostility to the liberalisation of regional trade and the construction of a regional market place. This has been particularly the case where mechanisms of compensation or active state promotion strategies are lacking, or alternatively in situations in which the liberalisation of regional trade entails the likely or actual retraction of state promotion mechanisms. Antipathy to the Mercosur over the 1990s was also found predominantly in those national firms that were not 
regionally competitive in their particular sector, and this wariness found special expression, not surprisingly, in those firms and sectors faced with significant competition from their Brazilian counterparts. For many-perhaps most-PYMEs, the extraction of meaningful value from the Mercosur was thus at best difficult. On the other hand, many PYMEs over the 1990s saw the Mercosur as proffering important opportunities for the expansion of their commercial activity and, consequently, their competitiveness. Given that participation in the wider 'global' economy was not a feasible option for the vast majority of PYMEs, the Mercosur was thus both a logical strategic focus and a springboard for the future development of more active internationalisation strategies. Francisco Gatto's (1995) surveys of Argentine PYMEs in the mid-1990s, for example, revealed that over half were committed to precisely such an expansion of their exchange with Mercosur countries, above all with Brazil, although proactive strategies of this sort remained in rather short supply. He also detected, moreover, a generalised perception of the potential benefits to be derived from co-operation between PYMES in the region, particularly in the interests of enhancing productive specialisation. Such perceptions notwithstanding, it should be emphasised that corporate strategies aiming at the Mercosur market remain predominantly the preserve of larger regional and transnational firms. Similarly, the process of market integration, while still in its early stages, remains driven by big business, often to the exclusion of smaller firms.

We should take care not to exaggerate the extent of inter-firm co-operation, whether we are talking about PYMEs, domestic firms or TNCs. Certainly the sorts of regional production networks that had emerged by the end of the 1990s in the NAFTA were not mirrored in corporate development in the Mercosur (UNCTAD, cited in Klein, 2000: 141). The point, nevertheless, is two-fold. First, the attraction of FDI is vital for the emerging internationalisation strategies of local firms, and the regional market constitutes a central incentive to inflows of FDI. Second, evidence suggests that the Mercosur arena is utilised increasingly as a 'stepping stone' to more global production strategies, and styled as an 'incubator' of industrial competitiveness for this purpose. With the launching of the FTAA project, this notion of the comparatively protected regional market as an 'incubator' has become particularly important. This is so primarily because of the lack of competitiveness of the bulk of Southern Cone products in both global and wider hemispheric marketplaces. Particularly in an FTAA in which minimal liberalisation is envisaged in agricultural trade or other key sectors, the lack of industrial competitiveness brings with it considerable adjustment costs for almost all economies. In Brazil the emerging form of hemispheric free trade is seen by some (particularly smaller and domestic-orientated) business sectors and the state to represent a sizeable threat. In Argentina as well, the emphasis has fallen on the costs of adjustment implied by hemispheric free trade for domestic and subregional economic interests. A survey by the Unión Industrial Argentina (Argentine Industrial Union, UIA) in 1998, for instance, suggested that $70 \%$ of Argentine firms did not feel prepared for an FTAA, and one assumes that the impact of the current crisis will have increased that proportion. It goes without saying that the subregional market remains crucial for the smaller economies. Towards the end of the 1990s the emphasis thus fell on the subregional arena 
(protected putatively by a common external tariff) as a site for the adjustment necessitated by a wider regionalist project.

\section{States and the reconfiguration of the regionalist project}

The result of these processes of market-led regionalisation-in conjunction with the various other social processes of regionalisation at work-has been not only the emergence of a new form of regional political economy in the Southern Cone, but also the reconfiguration of the regionalist governance project. Its significance thus lies, both empirically and conceptually, in the relationship it signifies between the regionalist project and broader regionalising processes: in other words, between the increasingly beleaguered and ponderous formal intergovernmental dimensions of the Mercosur, on the one hand, and on the processes of market regionalisation, on the other. Rather than advancing alongside the regionalist project, these regionalising trends have developed a marked independent momentum. The construction of a 'region', in this sense, is proceeding on a number of fronts, of which the formal intergovernmental front became perhaps the least robust over the course of the 1990s. It is in good part for this reason that the Mercosur project retains its rationale and utility, despite the profuse political obstacles to its further consolidation, and indeed despite the challenges issuing from an eventual FTAA. Crucially also, the regionalist dimensions of the regional governance project are increasingly orientated to underpinning these processes of market-led regionalisation, as a result of which they feature an important shift away from a dominant preoccupation with 'open regionalism' as a strategy of trade liberalisation, towards a set of regionalist strategies more attuned to the attraction of investment flows, and to industrial strategies to fostering the competitiveness of indigenous firms. Recent efforts to so redefine the Mercosur-such as its relaunching of 2000 and the flurry of talks in the early months of the Argentine crisis_can thus be seen as pointing towards the consolidation of an environment conducive to the entrenchment of the rules that undergird this form of regional governance structure.

The reconfiguration of the regionalist project, however, has at its root a reorganisation of the dominant form of state, which of course drives regionalist processes. In this regard, our above argument has a good deal in common with recent currents in the broad study of states and state strategies, in which the 'regulatory state' model has become one of the most favoured frameworks. This model has been applied most frequently to European states (McGowan \& Wallace, 1996; Wilks, 1996; Burnham, 1999), but increasingly to a number of Asian states (Jayasuriya, 2001) and further to the Chilean case (Muñoz Goma, 1996). In its broadest sense it refers to a process by which economic management becomes 'depoliticised' or else 'proceduralised': it is characterised by an increasingly rules-based and technocratic approach to economic governance, in which there is a greater emphasis on the operational independence of key institutions such as Central Banks. The functions of such a state are seen to be two-fold: first, to underpin markets and, second, to address market failures through the provision of various rights and goods (McGowan \& Wallace, 1996: 562). As such, the notion of the regulatory state has been developed in order to understand a 
situation characterised not by complete deregulation but rather also by key areas of re-regulation, particularly of financial markets (Gamble, 2000: 114; Burnham, 1999: 46). The regulatory state in this sense is fundamentally an enabling-rather than a planning or interventionist-one.

At first glance the regulatory state label seems rather problematic as a descriptor of the changing nature of states in the Southern Cone region. The implementation of neoliberal strategies both preceded and outstripped the development of regulatory regimes and capacities, reflecting enduring and pervasive institutional weakness. Privatisation took place without the previous preparation of the state to assume the role of regulator of competition and, except in Chile, central banks have not been accorded significant independence. The institutional realignments and operational independence associated with the depoliticisation of policy management and moves towards regulatory governance elsewhere thus find minimal expression in the Southern Cone. Nevertheless, the model is useful in identifying a particular mode of economic governance, notwithstanding the lag in the emergence of the appropriate state structures at the domestic level. Emerging elements of a depoliticised or regulatory style of economic management are especially visible in the elements of the model which emphasise external mechanisms of policy validation and the acceptance of binding rules for limiting government room for manoeuvre (see Burnham, 1999: 49). In the Southern Cone cases, such mechanisms most obviously include agreements with multilateral and financial institutions. While they are important to establishing credibility as well as necessary financing, however, it should be noted that these mechanisms of external validation remain perceived more as signs of weakness than as signs of economic health or as manifestations of an overall 'depoliticisation' of economic governance, and that their record of effectiveness has been a rather unhappy one. Mechanisms of external validation which have found rather firmer ground relate to the implantation of a rules-based policy-making environment. So-called codes of fiscal responsibility were agreed in Argentina and Brazil in the late 1990s; the regulatory characteristics of the Chilean state, which in any case approximates the model most closely, rest similarly on the principle of fiscal responsibility, along with a structure of financial regulation. Apart from being politically charged, especially in times of crisis, the implementation of such laws of fiscal responsibility is complicated by the aforementioned levels of institutional weakness, but nevertheless the drift at the domestic level has been towards the elaboration of such mechanisms, which aim to lay the foundations of a rules-based mode of economic governance.

Moreover, a central avenue by which such institutional and political obstacles are progressively addressed relates to strategies of regional co-ordination. On the one hand, such strategies are designed to reinforce rules-based economic governance by removing discretionary policy-making authority from individual national governments, and to compensate the institutional weaknesses at the domestic level which hamper the development of states' regulatory capacities. Of course, regional-level co-ordination is in itself a "mechanism of external validation', and is a key feature of regulatory styles of economic management. On the other hand, the process of market regionalisation of the sort we have described-resting heavily on the appeal of a regional economy of scale to TNCs 
and transnationalising domestic firms-requires both the maintenance of the rules governing such an arrangement between constituent countries, and the further harmonisation of domestic policies in order to increase the stability and attractiveness of this marketplace for private sector activity. The bulk of relevant regional initiatives in the late 1990s and early 2000s were tied up with the nascent progress of policy harmonisation, a first step towards which was statistical harmonisation in order to increase the accountability and transparency integral to regulatory styles of economic governance, and then progress towards the negotiation and agreement of common fiscal targets among Mercosur member countries. The issues of taxation and other economic policies that are necessary accompaniments to fiscal reform are also part and parcel of the emerging process of macroeconomic convergence. Most importantly, the negotiation of common investment rules and competition policy has been identified as central to the process of deepening and redefining integration in the Mercosur, and these are pivotal in constituting the emerging regional governance structure. Early movements in the area of competition policy turned out to be largely illusory - the 1996 Protocol for the Defence of Competition is still awaiting congressional approval to make it legally enforceable-but there has been a handful of subsequent initiatives which indicate some (slow) progress towards the agreement of some regional norms. Examples include the establishment in 2000 of a working group on investment incentives, and Argentina's 1999 Defence of Competition Law, which aligned Argentine competition policy more closely with Brazil's and is likely to facilitate the advance of harmonisation (Chudnovsky \& López 2003: 151). The consequence is that a movement towards a rules-based style of economic governance is reinforced by the imperative of maintaining for investors the coherence of the regional market and transparency in the policy rules which govern it.

The key point in all of this, however, relates not only to the ways in which regional co-ordination facilitates the elaboration of various state strategies, or to the ways in which the reorganisation of the state propels and underpins the reconfiguration of the regionalist project, but also to the ways in which the shape of domestic political economy is moulded by processes of regionalisation. As suggested earlier, this dimension of the relationship between domestic and regional processes is neglected as a consequence of the 'nation writ large' framework which pervades much of the study of regionalism. In other words, alongside our understanding of the ways in which regionalist projects emerge from and reinforce domestic processes, we need an understanding of the impact of regionalising forces on the shape of domestic political economies and processes of change within them. Our attention here to the reorganisation of the dominant form of state in the Southern Cone, propelled by processes of market-led regionalisation and manifested in the form of the regionalist project, thus suggests the need to dispense with the 'nation writ large' assumption and to seek, instead, to understand a much more complex relationship between regional and domestic political economy. It also underlines our earlier argument that a focus merely on formal regionalist processes is inadequate for understanding either the regional governance project underpinning the Mercosur, or indeed its viability. 


\section{Conclusions}

As in Asia, the original project of open regionalism in the Southern Cone appears effectively to have petered out. This is not, like in Asia, the immediate consequence of financial crisis: rather, it reflects a more protracted process of internal fragmentation which has stunted the evolution of the regionalist project beyond its early successes in the area of trade liberalisation, and which issues predominantly from the entrenched divergence of domestic political economy structures - and consequently what we have called 'visions of regionalism'among member countries. Although for different reasons, then, regionalism in both Asia and the Southern Cone is in a state of flux, and I have argued that a 'new' regional governance project is crystallising in the latter which represents quite a significant departure from the regionalism of the early 1990s. Pulling together the strands of the above arguments, I suggest that the 'new' regional governance project in the Southern Cone has three essential characteristics:

- The constitution of the region primarily through market-led and other regionalisation processes, which lend rationale and impetus to the maintenance of the regionalist project of the Mercosur.

- The reorganisation of the regionalist project to privilege investment attraction and industrial competitiveness, and to construct a rules-based governance foundation for the emerging regional marketplace.

- The dominance of strategic and political objectives in visions of the Mercosur project, focused on external negotiations, and reflected particularly in the articulation of Brazil's subregional leadership role.

This reorganisation of the regionalist project has taken place against the backdrop of an increasingly complex wider regional context, of which the negotiations for an eventual FTAA are the most salient dimension. The hemispheric project augurs a more messy and overlapping pattern of regionalist arrangements (which in many ways resembles patterns in the Asian region), and not, as the "hemispheric globalisation' rhetoric suggests, an absorption of the existing patchwork of regionalist projects into a single FTAA. Accommodation between these contending projects is consequently the primary challenge for regionalism, and indeed the contours of the Southern Cone project that have been sketched here reflect this context. There is a sense in which an FTAA represents an alternative regionalist project which will compensate for the numerous deficiencies of the Mercosur. Certainly a good number of the most obvious sticking points, such as services and investments, will be negotiated at the hemispheric level. This might well be used as part of an argument that the Mercosur will lose validity as much of the policy framework becomes standardised outside its borders. However, it is important to recognise that the Mercosur and FTAA processes are separate from one another, and are treated as such within the Mercosur. The central aims are similar-namely to eliminate export subsidies and to restrict the use of measures such as anti-dumping in trade relationships-but it is precisely these issues that might best be treated in the Mercosur, especially given the reluctance of the USA to open them for negotiation at the hemispheric level or in the wTO. Furthermore, 
there is no necessary correspondence between internal Mercosur policy and negotiating positions in the FTAA, and the activities of the national working groups and institutions that are involved in the FTAA negotiations are aimed exclusively in this direction. Consequently, in areas such as industrial policy, treatment of smaller and poorer economies, anti-dumping and restrictive trade practices, perhaps social policy, and perhaps even dispute resolution, the Mercosur presents an arena in which regionally appropriate policies (or those which fill the gaps left at the hemispheric level) might be designed. The contours of the new regional governance project, in this sense, are both compatible with, and shaped by, its emerging relationship with the wider regionalist process in the Americas.

In conceptual terms, I have argued that an understanding of contemporary regional governance in the Southern Cone, and indeed elsewhere, requires a much closer attention to processes of regionalisation and their relationship with the formal regionalist project. Regionalisation cannot be understood in the absence of a conception of regionalism: on the one hand, the latter seeks to accelerate, modify, or perhaps reverse these processes of social change and, on the other, it is pivotal in the continual reproduction of these structures (Gamble \& Payne, 1996: 250). What regionalism means, in essence, is that strategies of national economic management and the processes by which accumulation occurs (as well as the type of accumulation that is privileged) can be expected to undergo a redefinition. This redefinition involves a reconfiguration of social relations occurring over a regional, rather than a domestic, terrain and the emergence of common forms of market organisation and economic strategy.

However, regionalisation also needs to be conceptualised as constitutive of regionalism, and indeed the case of the Southern Cone suggests that, increasingly, it is the emerging dynamics and architecture of regionalisation that have lent rationale to the ailing regionalist project and have shaped the domestic and international strategies it represents. While the dynamism of regionalisation thus clearly depends on the articulation of a viable regionalist project which underpins the associated processes, progressively, the regionalist Mercosur project derives its meaning and impetus from these non-state and market-driven dynamics.

\section{Notes}

1 Mercado Común del Sur, or Southern Common Market, comprising Argentina, Brazil, Paraguay and Uruguay, with Chile and Bolivia currently as associate members.

2 I draw here on Anthony Payne and Andrew Gamble's (1996: 2) definitions of regionalism and regionalisation, the former referring to 'a state-led or states-led project designed to reorganise a particular regional space along defined economic and political lines', and the latter to 'a social process manifest at the regional level'. Following their lead, I use the adjective 'regionalist' specifically to refer to regionalism, and the adjective regional to denote the much broader context of both region and the conjunction of processes associated with regionalism and regionalisation.

3 It is interesting, in this regard, that one of the principal pillars of the Brazilian-driven push towards closer integration in the region was the creation of a South American-as opposed to Latin American or indeed hemispheric-identity, which would facilitate the construction of a South American Free Trade Area (SAFTA).

4 This phrase is borrowed from Hugo Radice (2000: 8), who uses it in the different context of the treatment of regions in the globalisation literature, referring to the tendency to treat a region as a nation in order to assert that globalisation can be condensed into a notion of regionalisation, and thereby to question the existence of the former. 
5 These myriad processes of regionalisation, and their constitution of a new regional political economy, are elaborated in my forthcoming The Southern Cone Model: The Political Economy of Regional Capitalist Development. The material in this section draws on this source.

6 Sociedad Macri. SOCMA classifies its activities principally in the fields of public services and infrastructure, automobiles, construction, food and information technology. See http://www.socma.com.ar for a profile of its interests, assets and activities.

'SOCMA: taking Mercosur seriously', Argentina Monthly, August 1999, at http://www.invertir.com.

8 See interview with Francisco Macri (president of SOCMA) for the Uruguayan radio station Radio El Espectador, 6 October 1999, at http://www.espectador.com/text/especial/macri.htm.

\section{References}

Bernier, I \& Roy, M (1999) NAFTA and Mercosur: two competing models?, in: G Mace, L Bélanger \& contributors (eds), The Americas in Transition: The Contours of Regionalism, pp 69-91 (Boulder, CO: Lynne Rienner).

Burnham, P (1999) The politics of economic management in the 1990s, New Political Economy, 4 (1), pp 37-54.

Cammack, P (2001) Mercosur and Latin American integration, in: K Radke \& M Wiesebron (eds), Competing for Integration: Japan, Europe and Latin America (New York: ME Sharpe).

Chudnovsky, D, Kosacoff, B \& López, A (1999) Las Multinacionales Latinoamericanas: Sus Estrategias En Un Mundo Globalizado (Buenos Aires: Fondo de Cultura Económica).

Chudnovsky, D \& López, A (2003) Policy competition for foreign direct investment, in: D Tussie (ed), Trade Negotiations in Latin America: Problems and Prospects, pp 135-154 (Basingstoke: Palgrave).

Da Motta Veiga, P (1999) Brasil en el Mercosur: política y economía en un proyecto de integración, in: J Campbell (ed), Mercosur: Entre la Realidad y la Utopía, pp 299-373 (Buenos Aires: Grupo Editor Latinoamericano).

de Paiva Abreu, M (2003) Latin American and Caribbean interests in the wTo, in: D Tussie (ed), Trade Negotiations in Latin America: Problems and Prospects, pp 19-31 (Basingstoke: Palgrave).

ECLAC (UN Economic Commission for Latin America and the Caribbean) (2001) Foreign Investment in Latin America and the Caribbean, 2000 Report (New York: United Nations).

Gamble, A (2000) Economic governance, in: J Pierre (ed), Debating Governance: Authority, Steering, and Democracy, pp 110-37 (Oxford: Oxford University Press).

Gamble, A \& Payne, A (1996) Conclusion: the new regionalism, in: A Gamble \& A Payne (eds), Regionalism and World Order, pp 247-264 (Basingstoke: Macmillan).

Gatto, F (1995) Las exportaciones industriales de pequeñas y medianas empresas, in: B Kosacoff (ed), Hacia una nueva estrategia exportadora: La experiencia argentina, el marco regional y las reglas multilaterales, pp 133-173 (Buenos Aires: Universidad Nacional de Quilmes).

INTAL (1997) Informe Mercosur No 3, 1996-1997 (Buenos Aires: BID-INTAL).

Jayasuriya, K (2001) Globalisation and the changing architecture of the state: regulatory state and the politics of negative coordination, Journal of European Public Policy, 8 (1), pp 101-123.

Kingstone, P (1999) Constitutional reform and macroeconomic stability: implications for democratic consolidation in Brazil, in: P Oxhorn \& PK Starr (eds), Markets and Democracy in Latin America: Conflict or Convergence?, pp 133-160 (Boulder, CO: Lynne Rienner).

Klein, W (2000) El Mercosur: Empresarios y sindicatos frente a los desafíos del proceso de integración (Caracas: Editorial Nueva Sociedad).

López, A \& Porta, F (1995) Nuevas modalidades de inserción internacional: el Mercosur', in: B Kosacoff (ed), Hacia Una Nueva Estrategia Exportadora: La Experiencia Argentina, El Marco Regional Y Las Reglas Multilaterales, pp 231-277 (Buenos Aires: Universidad Nacional de Quilmes).

McGowan, F \& Wallace, H (1996) Towards a European regulatory state, Journal of European Public Policy, 3 (4), pp 560-576.

Muñoz Gomá, O (1996) Hacia el estado regulador, in: O Muñoz Gomá (ed), Después de las Privatizaciones: Hacia el Estado Regulador, pp 19-47 (Santiago: CIEPLAN/Dolmen Ediciones).

Oliveira Holzhacker, D \& Guilhon Albuquerque, JA (2002) Attitudes and strategies of multinational enterprises about regional integration in Brazil, mimeo (Research Centre for International Relations, University of São Paolo), March.

Page, S (2001) Regional integration and the investment effect, in: V Bulmer-Thomas (ed), Regional Integration in Latin America and the Caribbean: The Political Economy of Open Regionalism, pp 45-64 (London: Institute of Latin American Studies).

Payne, A \& Gamble, A (1996) Introduction: the political economy of regionalism and world order, in: A Gamble \& A Payne (eds), Regionalism and World Order, pp 1-20 (Basingstoke: Macmillan).

Phillips, N (2003) Reconfiguring subregionalism: the political economy of hemispheric integration in the Americas, International Affairs, 79 (2), pp 257-279. 
Phillips, N (2001) Regionalist governance in the new political economy of development: 'relaunching' the Mercosur, Third World Quarterly, 22 (3), pp 565-583.

Phillips, N (2000) Governance after financial crisis: South American perspectives on the reformulation of regionalism, New Political Economy, 5 (3), pp 383-398.

Radice, H (2000) Responses to globalisation: a critique of progressive nationalism, New Political Economy, 5 (1), pp 5-19.

SELA (Sistema Económico Latinoamericano) (1999) Reflexiones sobre la dinámica de las relaciones externas de América Latina y el Caribe, Capítulos del SELA, 55, pp 7-57.

Wilks, S (1996) Regulatory compliance and capitalist diversity in Europe, Journal of European Public Policy, 3 (4), pp 536-359. 